\title{
Up-regulation of metallothionein isoforms in keloid keratinocytes
}

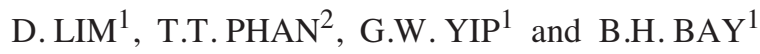 \\ ${ }^{1}$ Department of Anatomy, National University of Singapore, 4 Medical Drive, Singapore 117597; \\ ${ }^{2}$ Department of Surgery and Division of Bioengineering, National University of Singapore, \\ 5 Lower Kent Ridge Road, Singapore 119074
}

Received August 31, 2005; Accepted October 17, 2005

\begin{abstract}
Keloids are proliferative growths of dermal collagen, usually resulting from excessive tissue response during wound healing. There is evidence that keratinocytes may promote keloidogenesis via epithelial-mesenchymal interactions. Metallothioneins (MTs) are known to be involved in the fundamental cellular processes of growth and apoptosis. In this study, we evaluated the expression of MT isoforms in normal and keloid keratinocytes. The expression patterns of ten functional MT isoforms were assessed using real-time RT-PCR in primary cultures of normal and keloid keratinocytes. The MT-2A isoform was the most abundant MT isoform in both normal and keloid keratinocytes while the MT-1B isoform was absent. There was a significant increase in the mRNA expression of four MT isoforms, viz. MT-1A, $1 \mathrm{E}, 1 \mathrm{~F}$ and $2 \mathrm{~A}$ in keloid keratinocytes as compared to normal keratinocytes. Up-regulation of MT-1A, 1E, 1F and 2A isoforms may play a part in the development of keloids by paracrine signaling.
\end{abstract}

\section{Introduction}

A keloid is an abnormality of the skin that results during the process of recovering from a skin injury. Keloid formation involves atypical proliferation and overproduction of extracellular matrix $(1,2)$. Keloids occur when the scar matures and more collagen is produced than degraded, resulting in overgrowth of the skin and giving rise to an elevated and hyperaemic scar. As keloids extend beyond the injured site to invade the surrounding normal skin without spontaneous regression, they are considered as benign skin tumors.

MTs consist of a group of low molecular weight cysteinerich proteins that have metal-binding properties (3). The MT protein was first identified as a cadmium-binding protein in equine kidneys and subsequently purified and characterized

Correspondence to: Dr B.H. Bay, Department of Anatomy, Faculty of Medicine, National University of Singapore, 4 Medical Drive, Blk MD10, Singapore 117597

E-mail: antbaybh@nus.edu.sg

Key words: keloid, keratinocytes, metallothionein, real-time RT$\mathrm{PCR}$, wound healing by Kagi and Vallee (4) and Kagi et al (5). MTs have selective binding to metals such as zinc, copper and cadmium (6) and are involved in the detoxification of heavy metals such as cadmium and mercury. MTs are known to be associated with protection against DNA damage and oxidative stress (7). MTs have been implicated in the fundamental processes of cell proliferation, differentiation and apoptosis (8). There are $>10$ functional MT isoforms in humans, which encode four main groups of MT proteins viz. MT-1, MT-2, MT-3 and MT-4 proteins (9-11). The MT-1 protein comprises many subtypes encoded by a set of MT-1 genes (12).

There is cumulative evidence that keratinocytes may promote keloidogenesis via epithelial-mesenchymal interactions. In this study, we compared the mRNA expression of the functional MT-1A, 1B, 1E, 1F, 1G, 1H, 1X, 2A, 3 and 4 isoforms in primary cultures of keloid keratinocytes (KK) with normal keratinocytes (NK).

\section{Materials and methods}

Tissues. Fresh tissue specimens of earlobe keloid scars were used in this project. No patient had previously received treatment for the keloids and excised specimens were confirmed histopathologically. Control tissue and cells were derived from discarded normal adult skin samples removed during plastic surgery procedures. The collection of pathological and normal tissue samples were approved by the Institutional Ethics Board and with informed patient consent.

Primary keratinocyte cultures. Primary cultures of keratinocytes derived from keloids and normal tissues were seeded at a density of $4 \times 10^{5}$ cells and maintained for 2 days in EpiLife medium (Cascade Biologics, OR) until $80 \%$ confluent. The medium was then changed to EpiLife basal medium for $48 \mathrm{~h}$ before subjecting to total RNA extraction.

Transmission electron microscopy. A fresh keloid and normal skin specimens were fixed in $3 \%$ glutaraldehyde and $2 \%$ paraformaldehyde in phosphate buffer $(0.1 \mathrm{M}, \mathrm{pH} 7.4)$ overnight, as previously described (13). Briefly, osmification was carried out with $1 \%$ osmium tetroxide for $1 \mathrm{~h}$ at room temperature. Samples were dehydrated in an ascending series of ethanol and embedded in araldite. Ultrathin sections were then cut and mounted on formvar-coated copper grids. 

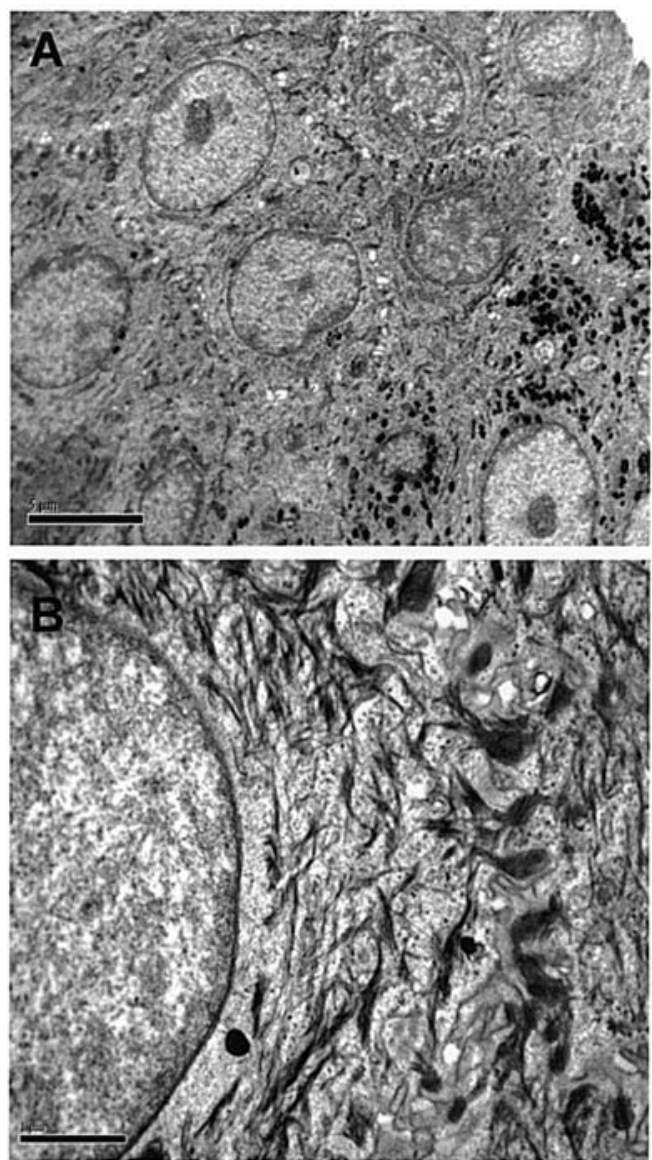

Figure 1. Electron micrograph of keloid keratinocytes (A) showing the distinct presence of keratofilaments at a higher magnification (B). Bar, $5 \mu \mathrm{m}$ (A); bar, $1 \mu \mathrm{m}(\mathrm{B})$.
Sections were double stained with uranyl acetate and lead citrate before examination with a Philips CM 120 BioTwin electron microscope.

Real-time RT-PCR. Total RNA was isolated from the normal and keloid keratinocytes by TRIzol extraction. The concentration and the quality of the RNA extracted were examined by spectrophotometric absorbance readings at 260 and $280 \mathrm{~nm}$. Five micrograms of total RNA isolates were transcribed into cDNA using SuperScript III 1st Strand Synthesis System (Invitrogen) with random hexamer primers following the manufacturer's protocol. The cDNA products were kept at $-20^{\circ} \mathrm{C}$ for real-time RT-PCR analysis. Each cDNA sample equivalent to $25 \mathrm{ng}$ of total RNA was then used in each real-time RT-PCR reaction. The primers specific for the individual MT isoforms were adapted from Mididoddi et al (11). Real-time RT-PCR conditions were optimized by adjusting the annealing temperature. PCR was performed using a LightCycler (Roche Diagnostics) in a total reaction mixture of $10 \mu 1$ containing 1X QuantiTect SYBR Green Master Mix (Qiagen), $0.5 \mu \mathrm{M}$ of each primer and $25 \mathrm{ng}$ of cDNA. After initial denaturation at $95^{\circ} \mathrm{C}$ for $15 \mathrm{~min}, 45$ cycles were performed at $94^{\circ} \mathrm{C}$ for $15 \mathrm{sec}, 60^{\circ} \mathrm{C}$ for $25 \mathrm{sec}$, and $72^{\circ} \mathrm{C}$ for $18 \mathrm{sec}$. Melting curve analysis was carried out at $65^{\circ} \mathrm{C}$ for $15 \mathrm{sec}$ to verify the specificity of the amplification reaction. Triplicate reactions for each specimen were performed. Relative quantification was calculated using the $\Delta \Delta C_{T}$ and 2- $\Delta \Delta C \mathrm{CT}$ method (14), where $\Delta \mathrm{C}_{\mathrm{T}}$ refers to the difference between the $\mathrm{C}_{\mathrm{T}}$ values of the target gene and the housekeeping gene, $\beta$ actin. The $C_{T}$ value is considered as the fractional cycle number at which the emitted fluorescence of the sample
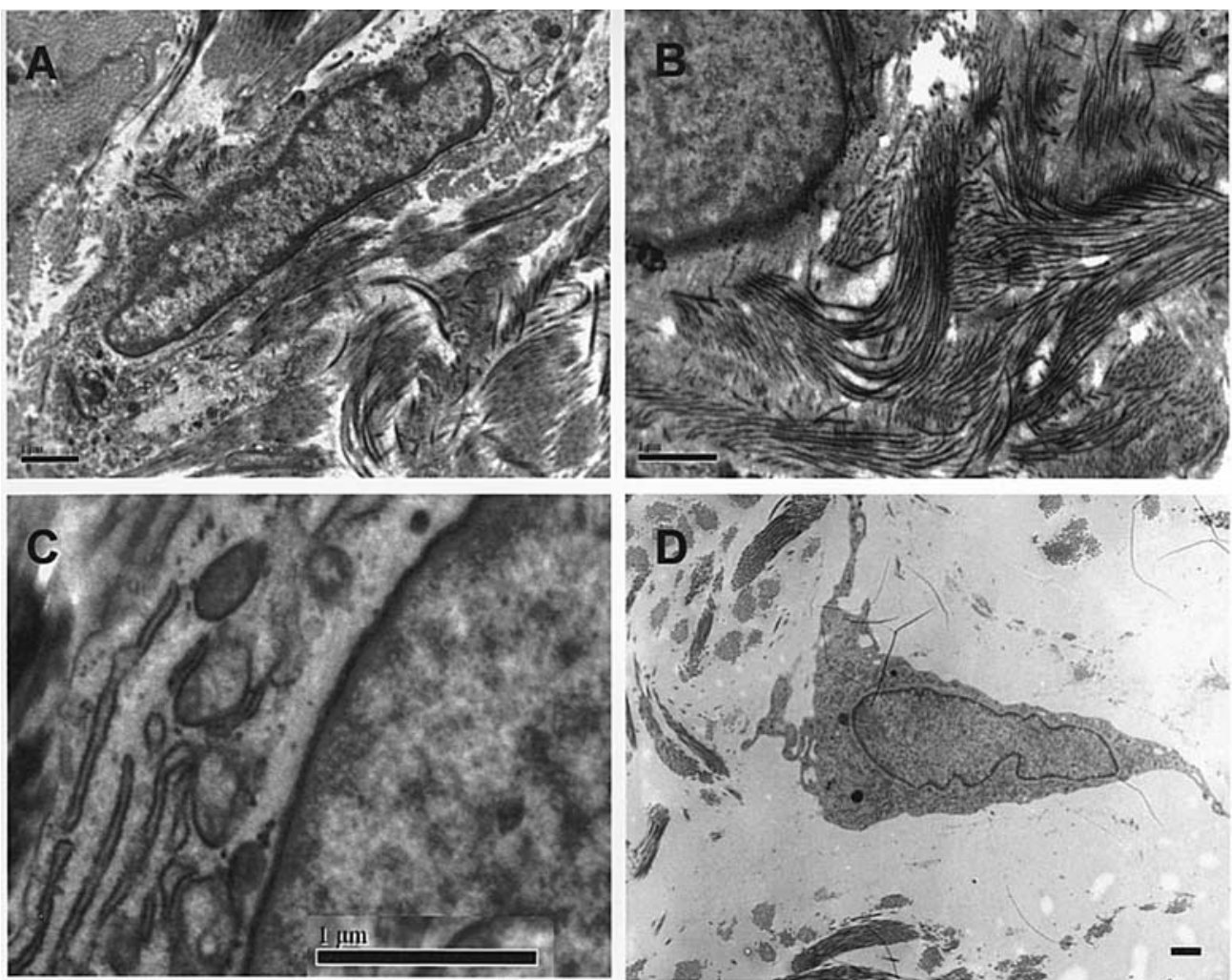

Figure 2. Electron micrographs of keloid fibroblasts (A-C) and normal skin fibroblast (D). Bar, $1 \mu \mathrm{m}$. 
Table I. Real-time RT-PCR analysis of MT isoforms in normal and keloid keratinocytes.

\begin{tabular}{|c|c|c|c|c|c|}
\hline Gene of interest & Samples & Gene $\mathrm{C}_{\mathrm{T}}$ values & Gene $\Delta \mathrm{C}_{\mathrm{T}}$ value & $\Delta \Delta \mathrm{C}_{\mathrm{T}}$ & P-value \\
\hline \multirow{2}{*}{ MT-1A } & NK & $35.67 \pm 1.70$ & $19.39 \pm 1.48$ & $0.00 \pm 1.75$ & \multirow[t]{2}{*}{$0.0036^{\mathrm{a}}$} \\
\hline & KK & $32.76 \pm 1.83$ & $14.83 \pm 1.09$ & $-3.89 \pm 1.17$ & \\
\hline \multirow[t]{2}{*}{ MT-1B } & NK & $\mathrm{NC}$ & $\mathrm{NC}$ & $\mathrm{NC}$ & \multirow[t]{2}{*}{$\mathrm{NC}$} \\
\hline & KK & $\mathrm{NC}$ & $\mathrm{NC}$ & $\mathrm{NC}$ & \\
\hline \multirow[t]{2}{*}{ MT-1E } & NK & $25.99 \pm 1.86$ & $9.24 \pm 1.00$ & $0.00 \pm 1.53$ & \multirow[t]{2}{*}{$0.0197^{\mathrm{a}}$} \\
\hline & KK & $23.98 \pm 1.74$ & $6.25 \pm 1.64$ & $-2.99 \pm 1.72$ & \\
\hline \multirow[t]{2}{*}{$\mathrm{MT}-1 \mathrm{~F}$} & NK & $33.99 \pm 1.65$ & $17.24 \pm 1.39$ & $0.00 \pm 1.39$ & \multirow[t]{2}{*}{$0.0413^{\mathrm{a}}$} \\
\hline & KK & $33.37 \pm 1.84$ & $15.64 \pm 0.48$ & $-1.60 \pm 0.48$ & \\
\hline \multirow[t]{2}{*}{$\mathrm{MT}-1 \mathrm{G}$} & NK & $36.35 \pm 2.45$ & $19.49 \pm 2.42$ & $0.00 \pm 2.45$ & \multirow[t]{2}{*}{0.5252} \\
\hline & KK & $36.35 \pm 1.20$ & $18.56 \pm 2.12$ & $-0.99 \pm 2.25$ & \\
\hline \multirow[t]{2}{*}{ MT-1H } & NK & $40.42 \pm 0.85$ & $23.68 \pm 0.97$ & $0.00 \pm 0.43$ & \multirow[t]{2}{*}{0.1581} \\
\hline & KK & $39.83 \pm 1.13$ & $22.05 \pm 2.13$ & $-1.64 \pm 0.95$ & \\
\hline \multirow[t]{2}{*}{ MT-1X } & NK & $23.83 \pm 0.98$ & $7.08 \pm 0.81$ & $0.00 \pm 0.81$ & \multirow[t]{2}{*}{0.5580} \\
\hline & KK & $25.22 \pm 2.57$ & $7.49 \pm 1.25$ & $0.41 \pm 1.25$ & \\
\hline \multirow[t]{2}{*}{ MT-2A } & NK & $23.45 \pm 2.07$ & $6.70 \pm 1.75$ & $0.00 \pm 1.75$ & \multirow[t]{2}{*}{$0.0112^{\mathrm{a}}$} \\
\hline & KK & $21.53 \pm 2.10$ & $3.81 \pm 0.92$ & $-2.89 \pm 0.92$ & \\
\hline \multirow[t]{2}{*}{ MT-3 } & NK & $\mathrm{NC}$ & $\mathrm{NC}$ & $\mathrm{NC}$ & \multirow[t]{2}{*}{$\mathrm{NC}$} \\
\hline & KK & $\mathrm{NC}$ & $\mathrm{NC}$ & $\mathrm{NC}$ & \\
\hline \multirow[t]{2}{*}{ МТ-4 } & NK & $\mathrm{NC}$ & $\mathrm{NC}$ & $\mathrm{NC}$ & \multirow[t]{2}{*}{$\mathrm{NC}$} \\
\hline & KK & $\mathrm{NC}$ & $\mathrm{NC}$ & $\mathrm{NC}$ & \\
\hline
\end{tabular}

ß-actin values for NK and KK are $16.75 \pm 0.86$ and $17.73 \pm 1.69$ respectively. Values shown are mean readings $\pm \mathrm{SD}$. ${ }^{\mathrm{a}} \mathrm{P}-\mathrm{value}<0.05$. NC, not computable.

passes a fixed threshold above the baseline. For each MT isoform, $\mathrm{NK}$ cells were selected as the reference. $\Delta \Delta \mathrm{C}_{\mathrm{T}}$ refers to the difference of the $\Delta \mathrm{C}_{\mathrm{T}}$ between the $\mathrm{KK}$ and $\mathrm{NK}$. Lower $\Delta C_{T}$ values and $\Delta \Delta C_{T}$ values reflect a relatively higher amount of MT transcript.

Statistical analysis. An unpaired two-tailed t-test was performed using GraphPad Prism version 4.00 for Windows (GraphPad Software).

\section{Results}

Keloid morphology. The keloid tissue has an epithelial and mesenchymal compartment. Ultrastructural examination showed that keratinocytes in the keloid tissue were characterized by bundles of keratin tonofilaments (Fig. 1). In the mesenchymal compartment, there was proliferation of spindleshaped fibroblasts with profuse deposition of collagen bundles (Fig. 2A) as opposed to the fibroblast seen with loose supporting collagenous tissue in normal skin (Fig. 2D). In this aberrant healing process, dense collagen fibers were deposited haphazardly and often as nodules in the dermis
(Fig. 2A and B). At higher magnification (Fig. 2C), the presence of prominent endoplasmic reticulum signifies the protein secretory function of the fibroblasts.

MT-isoform expression. The expression of the ten functional MT isoforms in normal and keloid keratinocytes as evaluated by real-time RT-PCR are shown in Table I. Both NK and KK cells expressed the MT-1A, 1E, 1F, 1G, 1H, $1 \mathrm{X}$ and $2 \mathrm{~A}$ isoforms. The MT-2A isoform was the most abundant MT isoform in both types of keratinocytes while the MT-1B mRNA transcript was absent. As the MT-3 and MT-4 isoforms showed either very low or no expression in NK and KK cells, they were considered as not computable. Expression of the the MT-1G and $1 \mathrm{H}$ isoforms were found to be low in both NK and KK. There was a significant difference in the expression of MT-1A, 1E, 1F and 2A isoforms in keloid keratinocytes as compared with normal keratinocytes (Table I). As shown in Fig. 3, the relative change in MT-1A was approximately 14.8-fold, MT-1E 7.9-fold, MT-1F 3.0-fold and MT-2A 7.4fold. The specificity of the MT-1A (219 bp), MT-1E (284 $\mathrm{bp})$, MT-1F (232 bp) and MT-2A (259 bp) PCR products is shown in Fig. 4. 


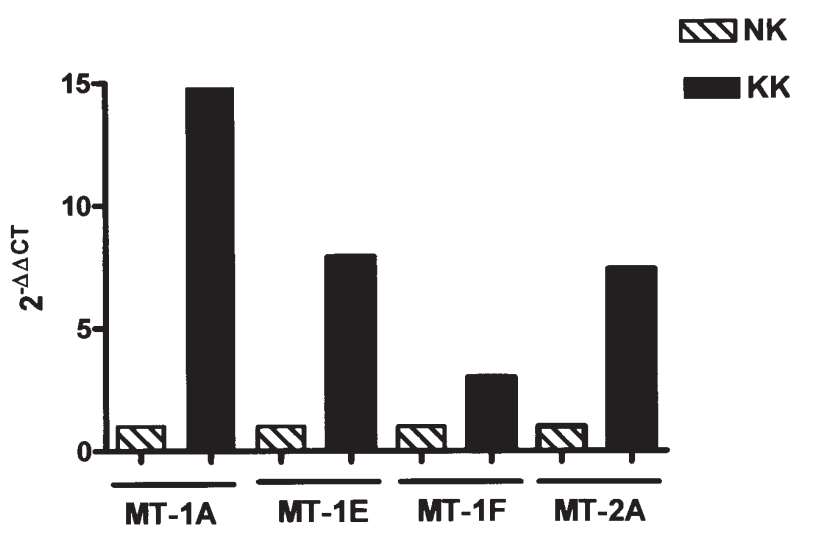

Figure 3. Relative expression levels (average fold-change) of the four upregulated MT isoforms; MT-1A, MT-1E, MT-1F and MT-2A in keloid keratinocytes (KK) with normal (NK) keratinocytes as the calibrator.

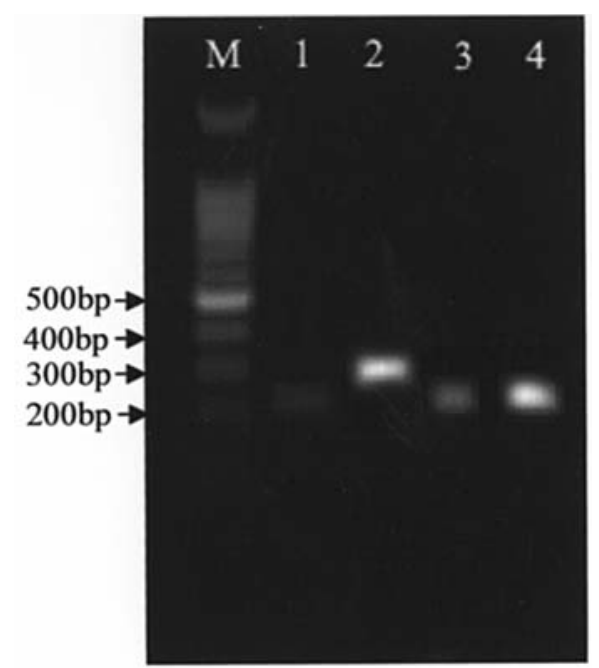

Figure 4. Gel electrophoresis photograph showing the PCR products of MT1A, MT-1E, MT-1F and MT-2A genes in keloid keratinocytes. 100 bp DNA marker (lane M), MT-1A (lane 1), MT-1E (lane 2), MT-1F (lane 3) and MT2A (lane 4)

\section{Discussion}

Wound healing is a complex process that involves the interaction of the epidermis and dermis. Keloidogenesis occurs when there is an abnormality in the proliferation and apoptosis of the fibroblasts in the dermal layer. However, this is not an isolated dermal disease as many studies have shown that epidermal-mesenchymal interactions play an important role in the formation of keloids (15-18).

There has been compelling evidence that autocrine, paracrine, and endocrine epithelial-mesenchymal interactions play a major role in normal skin homeostasis, growth, and differentiation $(19,20)$. Keratinocytes are found to promote proliferation and inhibit apoptosis of the underlying fibroblasts in keloidogenesis (21). Lim et al has also reported that keratinocytes of keloid tissue has profound effects on the production and organization of collagen by fibroblasts in the dermis (17). These findings strongly indicate that the overlying keratinocytes play an important role in promoting the growth and apoptosis of the underlying fibroblasts. Moreover, many signaling proteins such as kinases, Bcl-2 and TGF- 3 were found to be expressed more in keloid fibroblasts co-cultured with keloid keratinocytes as compared to normal keratinocytes $(18,22)$.

We examined MT expression in normal and keloid keratinocytes. MT is known to be expressed in the basal keratinocytes of normal skin and overexpressed in infiltrating basal cell carcinomas (23). In the present study, we observed for the first time that MT-1A, 1E, $1 \mathrm{~F}, 1 \mathrm{X}$ and $2 \mathrm{~A}$ isoforms were significantly expressed in KK as compared to NK cells. Thus far, the functional isoforms of MT have been reported to be involved in different functions. The MT-2A isoform is associated with cell proliferation (24), whereas both MT-1A and $2 \mathrm{~A}$ isoforms are reported to protect against apoptosis and oxidative stress (25). It has also been posited that MT$1 \mathrm{~F}$ and MT-2A isoforms may be involved in histological differentiation $(24,26)$. However, all MTs have characteristic cys- $\mathrm{X}-\mathrm{cys}$, cys- $\mathrm{X}-\mathrm{y}-\mathrm{cys}$, and cys-cys sequences (where $\mathrm{x}$ and $\mathrm{y}$ are non-cysteine amino acids) which are believed to bind a total of seven bivalent metal ions in two separate clusters (27).

The MT/thionein (MT/T) system is known to regulate and control the concentration and availability of zinc (28). The MT/T system has the capability to sequester zinc and at the same time release zinc when required (29). Bound zinc is released possibly as a result of oxidation and reduction of cysteine sulfur ligands present in MT (30). The role of zinc in modulating cell signaling, second messenger metabolism, stimulation of protein kinase phosphorylation and inhibition of protein phosphatase activity is well established (31). Moreover, zinc is a structural element of a huge number of transcription factors which contain zinc finger domains (32). The association of zinc with a multitude of biological functions and its related implications in health and disease, has led to this metal being touted as 'the calcium of the twenty-first century' (33).

As zinc promotes cell proliferation and differentiation as well as inhibits apoptosis (31), release of zinc by keloid keratinocytes could potentially serve as extracellular signals for the underlying fibroblasts to proliferate and produce collagen indiscriminately. Also, a lack of apoptotic mechanisms in keloids may play a pivotal role as alteration of oncogenes associated with apoptosis has also been previously reported (22). Conversely, sequestration of zinc in keratinocytes may reduce the availability of zinc to the underlying fibroblasts and low zinc levels inhibit collagenases, favoring collagen deposition $(34,35)$.

In conclusion, modulation of MT-1A, $1 \mathrm{E}, 1 \mathrm{~F}$ and $2 \mathrm{~A}$ isoforms observed in this study may play a regulatory role in keloid formation by paracrine signaling. We postulate that up-regulation of MT in keratinocytes could induce the development of keloids via zinc signaling cascades. Further studies using keloid keratinocytes co-cultured with normal or keloid fibroblasts would be necessary to elucidate the role of these MT isoforms in keloidogenesis.

\section{Acknowledgements}

This work was supported by grants from the Biomedical Research Council, Singapore (02/1/21/19/106) and National 
Medical Research Council, Singapore (NMRC/0612/2001). The authors are grateful to Ms. Y.G. Chan and Dr Qiong Cao for assistance in electron microscopy.

\section{References}

1. Babu M, Diegelmann R and Oliver N: Fibronectin is overproduced by keloid fibroblasts during abnormal wound healing. Mol Cell Biol 9: 1642-1650, 1989.

2. Swann DA, Garg HG, Jung W and Hermann H: Studies on human scar tissue proteoglycans. J Invest Dermatol 84: 527-531, 1985.

3. Ebadi M, Leuschen MP, El-Refaey H, Hamada FM and Rojas P: The antioxidant properties of zinc and metallothionein. Neurochem Int 29: 159-166, 1996.

4. Kagi JH and Valee BL: Metallothionein: a cadmium- and zinccontaining protein from equine renal cortex. II. Physicochemical properties. J Biol Chem 236: 2435-2442, 1961.

5. Kagi JH, Himmelhoch SR, Whanger PD, Bethune JL and Vallee BL: Equine hepatic and renal metallothioneins. Purification, molecular weight, amino acid composition, and metal content. J Biol Chem 249: 3537-3542, 1974.

6. Kagi JH and Schaffer A: Biochemistry of metallothionein. Biochemistry 27: 8509-8515, 1988

7. Chubatsu LS and Meneghini R: Metallothionein protects DNA from oxidative damage. Biochem J 291: 193-198, 1993.

8. Cherian MG, Jayasurya A and Bay BH: Metallothioneins in human tumors and potential roles in carcinogenesis. Review. Mutat Res 533: 201-209, 2003.

9. Stennard FA, Holloway AF, Hamilton J and West AK: Characterization of six additional human metallothionein genes. Biochim Biophys Acta 1218: 357-365, 1994.

10. Palmiter RD, Findley SD, Whitmore TE and Durnam DM: MT-III, a brain specific member of the metallothionein gene family. Proc Natl Acad Sci USA 89: 6333-6337, 1992.

11. Mididoddi S, McGuirt JP, Sens MA, Todd JH and Sens DA: Isoform-specific expression of metallothionein mRNA in the developing and adult human kidney. Toxicol Lett 685: 17-27, 1996.

12. Karin M, Eddy RL, Henry WM, Haley LL, Byers MG and Shows TB: Human metallothionein genes are clustered on chromosome 16. Proc Natl Acad Sci USA 81: 5494-5498, 1984.

13. Bay BH, Chan YG, Yick TY and Leong HK: Electron microscopic observations and X-ray microanalysis of a multinucleated giant cell. J Electron Microsc 47: 359-361, 1998.

14. Livak KJ and Schmittgen TD: Analysis of relative gene expression data using real-time quantitative PCR and the $2^{-\triangle \Delta C T}$ method. Methods 25: 402-408, 2001.

15. Le Poole IC and Boyce ST: Keratinocytes suppress transforming growth factor-betal expression by fibroblasts in cultured skin substitutes. Br J Dermatol 140: 409-416, 1999.

16. Lim IJ, Phan TT, Song C, Tan WT and Longaker MT: Investigation of the influence of keloid-derived keratinocytes on fibroblast growth and proliferation in vitro. Plast Reconstr Surg 107: 797-808, 2001.

17. Lim IJ, Phan TT, Bay BH, Qi R, Huynh H, Tan WT, Lee ST and Longaker MT: Fibroblasts cocultured with keloid keratinocytes: normal fibroblasts secrete collagen in a keloid like manner. Am J Physiol 283: C212-C222, 2002.
18. Xia W, Phan TT, Lim IJ, Longaker MT and Yang GP: Complex epithelial-mesenchymal interactions modulate transforming growth factor- $\beta$ expression in keloid-derived cells. Wound Rep Reg 12: 546-556, 2004.

19. Maas-Szabowski N, Shimotoyodome A and Fusenig NE: Keratinocyte growth regulation in fibroblast co-cultures via a double paracrine mechanism. J Cell Sci 112: 1843-1853, 1999.

20. MacKenzie IC: Epithelial-mesenchymal interactions in the development and maintenance of epithelial tissues. In: The Keratinocyte Handbook. Leigh I, Lane B and Watt F (eds). Cambridge University Press, Cambridge, pp243-257, 1994.

21. Funayama E, Chodon T, Oyama A and Sugihara T: Keratinocytes promote proliferation and inhibit apoptosis of the underlying fibroblasts: an important role in the pathogenesis of keloid. J Invest Dermatol 121: 1326-1331, 2003.

22. Teofoli P, Barduagni S, Ribuffo M, Campanella A, De Pita' O and Puddu P: Expression of Bcl-2, p53, c-jun and c-fos protooncogenes in keloids and hypertrophic scars. J Dermatol Sci 22: $31-37,1999$

23. Rossen K, Haerslev T, Hou-Jensen K and Jacobsen GK: Metallothionein expression in basaloid proliferations overlying dermatofibromas and in basal cell carcinomas. Br J Dermatol 136: 30-34, 1997.

24. Jin R, Chow VT, Tan PH, Dheen ST, Duan W and Bay BH: Metallothionein 2A expression is associated with cell proliferation in breast cancer. Carcinogenesis 23: 81-86, 2002.

25. Lu H, Hunt DM, Ganti R, Davis A, Dutt K, Alam J and Hunt RC: Metallothionein protects retinal pigment epithelial cells against apoptosis and oxidative stress. Exp Eye Res 74: 83-92, 2002.

26. Jin R, Bay BH, Chow VT and Tan PH: Metallothionein 1F mRNA expression correlates with histological grade in breast carcinoma. Breast Cancer Res Treat 66: 265-272, 2001.

27. Kagi JH and Hunziker P: Mammalian metallothionein. Biol Trace Elem Res 21: 111-118, 1989.

28. Tapiero $\mathrm{H}$ and Tew KD: Trace elements in human physiology and pathology: zinc and metallothioneins. Biomed Pharmacother 57: 399-411, 2003.

29. Vasak M and Kagi JH: Metallothioneins. In: Encyclopedia of Inorganic Chemistry. Vol. 4. King RB (ed). Wiley, New York, pp2229-2241, 1994.

30. Maret W and Vallee B: Thiolate ligands in metallothionein confer redox activity of zinc clusters. Proc Natl Acad Sci USA 95: 3478-3482, 1998.

31. Beyersmann D and Haase H: Functions of zinc in signaling, proliferation and differentiation of mammalian cells. Biometals 14: 331-341, 2001.

32. Berg JM and Shi Y: The galvanization of biology: a growing appreciation for the roles of zinc. Science 271: 1081-1085, 1996.

33. Frederickson CJ, Koh JY and Bush AI: The neurobiology of zinc in health and disease. Nat Rev Neurosci 6: 449-462, 2005.

34. Camps J, Bargallo T, Gimenez A, Alie S, Caballeria J, Pares A, Joven J, Masana L and Rodes J: Relationship between hepatic lipid peroxidation and fibrogenesis in carbon tetrachloridetreated rats: effect of zinc administration. Clin Sci 83: 695-700, 1992.

35. Jones WK: A murine model of alcoholic cardiomyopathy: a role for zinc and metallothionein in fibrosis. Am J Pathol 167: 301-304, 2005. 